\section{Leak leaves Antarctic observatory blinded}

A robotic observatory atop a plateau in eastern Antarctica has shut down after an exhaust leak caused its generator module to overheat. A Chinese expedition installed the PLATeau Observatory (PLATO) in January at Dome $\mathrm{A}$, the highest point in eastern Antarctica at 4,100 metres altitude (see Nature 451, 752; 2008). The observatory had operated continuously for 204 days before the leak. It is hoped that solar power will revive some of PLATO's instruments by the end of August, as spring nears.

PLATO has four 14.5-centimetre telescopes and weather instruments to test conditions at the site, which is one of the coldest and driest places on Earth. The Polar Research Institute of China has plans to return to the site next year to add three 50-centimetre telescopes.

\section{US ocean agency upgrades its research fleet}

The US National Oceanic and Atmospheric Administration (NOAA) has retired the last of its wooden-hulled ships on the same day it commissioned a modern research vessel.

On 13 August, the John N. Cobb was retired in Seattle, Washington, after 58 years of service. The ship conducted fishery studies off the coast of Alaska and was reportedly kept running with parts scavenged from nautical museums.

Joining the fleet is the Okeanos Explorer, which NOAA purchased from the US navy in 2004. The agency has upgraded the ship, adding two unmanned submersible vehicles, a satellite communications system for conducting experiments remotely and a fresh coat of white paint. The Okeanos Explorer

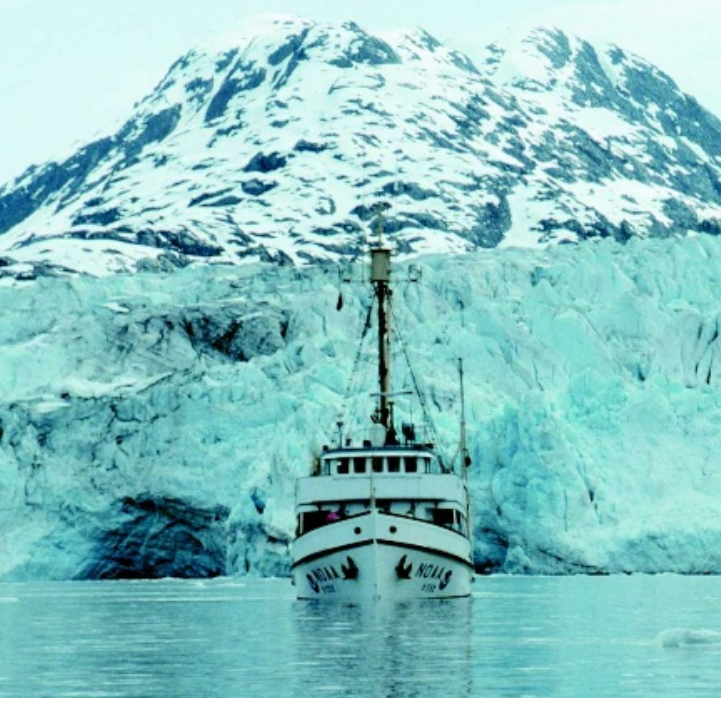

The John N. Cobb has been retired after 58 years.

\title{
New species of robin found in Gabon
}

\begin{abstract}
Ornithologists from the US Smithsonian Institution have identified a tiny fiery breasted robin as a new species.

The olive-backed forest robin (Stiphrornis pyrrholaemus) was first found on an expedition to forests in southwest Gabon in 2001, but it was thought to be a juvenile of a known species. The researchers have now confirmed that the robin is a distinct species by comparing its vocalizations and genetic code with those of other specimens in the Smithsonian's collection. The finding was published last week in the journal Zootaxa.
\end{abstract}

will specialize in mapping and basic exploration of interesting sites. After field testing, the vessel will head to the tropical Pacific.

\section{Computer experts blast ruling to gag students}

Computer scientists in the United States have condemned a court order that blocks three undergraduates from the Massachusetts Institute of Technology in Cambridge from discussing aspects of their research on the security of Boston's transit system.

The Massachusetts Bay Transportation Authority sought the order to prevent the students from giving a talk entitled "Anatomy of a Subway Hack" at a major convention in Las Vegas, Nevada. The talk exposed flaws in the transit system's 'smart cards', which are used for electronic ticketing.

In a letter supporting the students, 11 leading computer scientists warn that such restraining orders "will stifle research efforts and weaken academic computing research programmes".

As Nature went to press, a decision on whether to lift or amend the order was pending.

\section{Plans for the largest ever solar-power plants}

A utility company in the California has inked a deal for two massive solar-panel projects.

San Francisco-based Pacific Gas and Electric Company (PG\&E) agreed last week to purchase power from two solar-panel manufacturers in the state. OptiSolar, based in Hayward, will build a 550-megawatt plant, to be accompanied by a 250-megawatt plant from SunPower of San Jose.

To date, photovoltaics have been relegated to relatively small projects, measured in the tens of megawatts. PG\&E's 800-megawatt scheme would exceed the largest solar panel project in operation today by a factor of more than 30 , and its power capacity could rival that of a mid-sized coal-fired power plant.

The plants are scheduled to be fully operational by 2013, but are contingent on new transmission lines and the extension of federal tax credits for renewable energy.

\section{Science illustration course draws to an end}

An award-winning science illustration programme at the University of California, Santa Cruz, is facing closure.

On 12 August, administrators announced that they would end the programme next spring because of mounting debt in the university's continuing-education system. The 27-year-old science illustration course, one of a handful in the nation to offer graduate training, failed to bring in enough tuition dollars to cover its costs. The announced closure is the latest in a series of cuts.

The university is still looking for alternative ways to finance the illustration curriculum, says Ann Caudle, the course's director. "There is a sliver of a chance we might continue the programme.”

\section{Correction}

The News Feature 'The green menace' (Nature 452, 148-150; 2008) failed to give the full name and affiliation of Jan Leach, a plant pathologist at Colorado State University in Fort Collins. 